KALAMATIKA Jurnal Pendidikan Matematika

Volume 2, No. 2, November 2017, hal. 207-220

$\mathbf{K} \backslash \mathbf{L} \wedge \mathbf{M} / \mathbf{T} \mid \mathbf{K} \wedge$

\title{
PENGGUNAAN MODEL PjBL UNTUK MENINGKATKAN KREATIVITAS MAHASISWA DALAM MEMBUAT MEDIA PEMBELAJARAN MATEMATIKA
}

\author{
Dede Trie Kurniawan \\ Universitas Swadaya Gunung Jati \\ dedetriekurniawan@fkip-unswagati.ac.id
}

\begin{abstract}
ABSTRAK
Penelitian ini bertujuan menganalisis tingkat ketercapain tujuan penggunaan model PjBL dalam meningkatkan kreatifitas mahasiswa calon guru matematika untuk membuat media pembelajaran berbasis budaya lokal Cirebon. Salah satu keterampilan yang harus dimiliki oleh calon guru matematika adalah mampu dan dapat mempersiapkan serta menggunakan media pembelajaran dalam proses kegiatan belajar mengajar di kelas. Salah satu matakuliah yang mempersiapkan calon guru matematika agar memiliki kompetensi yang baik dalam penggunaan media pembelajaran adalah matakuliah Multimedia pembelajaran matematika untuk mahasiswa tingkat III dengan bobot 2 SKS. Hasil Penelitian menunjukan sebanyak $42 \%$ sangat setuju, $32 \%$ setuju bahwa model PjBL cocok dalam perkulihan media pembelajaran matematika berbasis budaya lokal untuk mahasiswa calon guru matematika. Peningkatan kreatifitas dapat dilihat dari sebagian besar produk media alat perga atau alat permainan edukatif matematika dapat masuk dalam kategori kreatif dengan indikator menampilkan ide modifikasi dari yang ada dan layout menarik. Budaya dan kearifan lokal cirebon dapat dijadikan sebagai salah satu bentuk media pembelajaran inovatif dalam pembelajaran matematika. Melalui matakuliah media pembelajaran diharapkan mahasiswa calon guru dapat mengenal kebudayaannya. Adapun kegiatan berpikir kreatif yang dimaksud adalah bagaimana mahasiswa akan mengaitkan antara teori pembelajaran, pengetahuan akan media pembelajaran dan kearifan budaya lokal cirebon.
\end{abstract}

Kata Kunci: Media Pembelajaran, Kearifan Lokal, Model PjBL, Kontekstual.

\begin{abstract}
This study aimed to analyze the level of achievement of the objectives in improving the use of the model PPA creativity mathematics student teachers to create media-based learning of local culture Cirebon. One of the skills that must be owned by prospective teachers of mathematics are capable and able to prepare and use instructional media in the process of teaching and learning activities in class. One of the subjects that prepare prospective teachers of mathematics, in order to have a good competence in the use of instructional media, is Multimedia learning of mathematics subject for third level students with 2 credits point. Culture and local wisdom of Cirebon can be used as one form of media innovative learning in mathematics. It is time for local wisdom cirebon be a source of learning for students. Through the course of learning media is expected student teachers can get to know the culture. The introduction of local culture to students urgently needed so that they can live their culture and themselves. The activities of creative thinking in question is how the students will be the link between learning theory, knowledge of instructional media and cultural wisdom of Cirebon.
\end{abstract}


Keywords: Instructional Media, Mathematics Education, Local Wisdom, PjBL Model.

Format Sitasi: Kurniawan, D.T. (2017). Penggunaan Model PjBL untuk Meningkatkan Kreativitas Mahasiswa dalam Membuat Media Pembelajaran Matematika. KALAMATIKA Jurnal Pendidikan Matematika. 2(2), 207-220.

Penyerahan Naskah: 12 Juli 2017 || Revisi: 28 Juli 2017 || Diterima: 4 Agustus 2017

\section{PENDAHULUAN}

Salah satu keterampilan yang harus dimiliki oleh calon guru matematika adalah mampu dan dapat mempersiapkan serta menggunakan media pembelajaran dalam proses kegiatan belajar mengajar dikelas. Media adalah segala sesuatu yang dapat digunakan untuk menyalurkan pesan dari pengirim kepada penerima. Media yang berfungsi untuk menyampaikan pesan pembelajaran sehingga dapat merangsang pikiran, perasaan, perhatian, dan minat siswa yang menjurus kearah terjadinya proses belajar disebut dengan media pembelajaran. Media pembelajaran adalah alat, metode dan teknik yang digunakan dalam rangka lebih mengefektifkan komunikasi dan interaksi antara guru dan siswa dalam proses pembelajaran di sekolah.

Salah satu matakuliah yang mempersiapkan calon guru matematika agar dapat memiliki kompetensi yang baik dalam penggunaan media pembelajaran adalah matakuliah Multimedia pembelajaran matematika untuk mahasiswa tingkat III yang berbobot 2 SKS. Mata Kuliah ini dimaksudkan untuk memberikan dasar pengetahuan dan membuat kreasi media pembantu penyampaian pembelajaran matematika. Topik - topiknya meliputi : peran dan fungsi media dalam proses pembelajaran, Mind map sebagai media sederhana, Peran TIK dalam media pembelajaran, wapik sebagai wahana web inovatif, ethnomatematic dan etnosains dan kumpulan artikel media alat peraga dan alat permainan edukatif dalam pembelajaran matematika.. Adapaun yang menjadi capaian dari matakuliah ini yaitu Mampu menghasilkan produk media pembelajaran berbasis budaya lokal dalam menunjang kegiatan pembelajaran Matematika serta dapat mempraktekan dengan cara penggunaan dan pemanfaatanya di kelas (Kurniawan 2013).

Budaya dan kearfian lokal cirebon dapat dijadikan sebagai salah satu bentuk media pembelajaran inovatif dalam pembelajaran matematika (Turmudi 2013). Sudah saatnya kearifan lokal cirebon menjadi sumber belajar bagi siswa. Praktek pendidikan berbasis kearifan lokal dapat digolongkan dalam berbagai ranah seperti pengobatan, seni beladiri, 
lingkungan hidup, pertanian, ekonomi, sistem penanggalan dan lain lain. Salah satunya adalah pemanfaatan kearifan lokal seperti permainan dan juga kekhasan daerah menjadi suatu bentuk media pembelajaran. Etnopedagogi yang satunya ditunjau dari penggunaan media pembelajaran ini bercirikan bekembang berdasarkan pengalaman, telah teruji lama, mudah diadaptasi dengan kultur kini, padu dalam praktek keseharian masyarakat/lembaga, lazim dilakukan oleh individu/masyarakat, bersifat dinamis dan mengandung sistem kepercayaan (Alwasiyah, Suryadi \& Karyono 2009; Suratno 2010; Rustaman 2014).

Melalui matakuliah media pembelajaran ini diharapkan mahasiswa calon guru dapat mengenal kebudayaannya. Pengenalan terhadap budaya lokal kepada peserta didik sangat diperlukan sehingga mereka dapat menghayati budayanya dan dirinya sendiri.

Pembelajaran Berbasis Proyek merupakan model pembelajaran yang didukung oleh atau berpijak pada teori belajar konstruktivistik (Purnawan 2007). Strategi pembelajaran yang menonjol dalam pembelajaran konstruktivistik antara lain adalah strategi belajar kolaboratif, mengutamakan aktivitas mahasiswa daripada aktivitas dosen, mengenai kegiatan laboratorium, pengalaman lapangan, studi kasus, pemecahan masalah, panel diskusi, diskusi, brainstorming, dan simulasi (Ajeyalemi 1993). Beberapa dari strategi tersebut juga terdapat dalam Pembelajaran Berbasis Proyek, yaitu (a) strategi belajar kolaboratif, (b) mengutamakan aktivitas mahasiswa daripada aktivitas guru, (c) mengenai kegiatan laboratorium, (d) pengalaman lapangan, (e) dan pemecahan masalah. Peranan dosen yang utama adalah mengendalikan ide-ide dan interpretasi mahassiwa dalam belajar, dan memberikan alternatifalternatif melalui aplikasi, bukti-bukti, dan argumen-argumen. Model ini dipandang cocok untuk memfasilitasi kegiatan penyaluran kreatifitas mahasiswa dalam matakuliah media pembelajaran. Berpikir kreatif merupakan suatu proses yang digunakan ketika kita mendatangkan/memunculkan suatu ide baru. Hal itu menggabungkan ide-ide yang sebelumnya yang belum dilakukan. Kreativitas merupakan produk berpikir kreatif seseorang. Berpikir kreatif juga dapat diartikan sebagai suatu kombinasi dari berpikir logis dan berpikir divergen yang didasarkan pada intuisi tetapi masih dalam kesadaran. Hal ini bermakna bahwa kegiatan berpikir kreatif adalah bagaimana mahasiswa akan mengaitkan antara teori pembelajaran, pengetahuan akan media pembelajaran dan kearifan budaya lokal cirebon. 
Berdasarkan latar belakang di atas, maka dilakukan penelitian dengan judul Penggunaan model PjBL untuk meningkatkan kreatifitas mahasiswa calon guru matematika dalam membuat media pembelajaran berbasis budaya lokal cirebon.

\section{METODE PENELITIAN}

Penelitian ini dilakukan pada program studi pendidikan matematika FKIP Unswagati Cirebon. Studi ini dilakukan untuk mengetahui kreatifitas mahasiswa calon guru matematika dalam membuat media pembelajaran matematika berbasis budaya lokal. Mahasiswa calon guru matematika yang dimaksud adalah mahasiswa semester 6 yang mengontrak mata kuliah

Multimedia pembelajaran matematika pada program studi pendidikan matematika di FKIP Unswagati Cirebon. Berikut ini pengumpulan data berupa:

1. Observasi langsung

Melakukan Observasi langsung ke kampus program studi pendidikan matematika FKIP Unswagati Cirebon. Observasi dilakukan pada saat pembelajaran berlangsung di kampus. Observasi ini dilakukan untuk menggali informasi segala hal mengenai kreatifitas mahasiswa calon guru matematika dalam mengikuti perkuliahan multimedia pembelajaran matematika.

2. Angket

Angket yang disebar kepada mahasiswa adalah Angket untuk menjaring respon/tanggapan mengenai penggunaan model $\mathrm{PjBL}$ bagi mahasiswa calon guru matematika dalam mengikuti perkuliahan multimedia pembelajaran matematika.

\section{Wawancara}

Wawancara dilakukan dengan dosen, mahasiswa dan ahli yang bertujuan untuk mengetahui kefektifan metode pembelajaran yang digunakan, hambatan yang dihadapi dosen dalam memberikan perkuliahan. Selain itu, wawancara dilakukan kepada beberapa mahasiswa calon guru matematika untuk mengetahui proses berpikir kreatifitas lainya yang kurang terungkap melalui angket dan observasi.

4. Analisis Dokumen dan Produk Media pembelajaran

Setelah melihat hasil angket mahasiswa calon guru matematika dan hasil wawancara dengan pihak yang terkait dengan penelitian, untuk lebih meyakinkan hasil laporan maka dokumen-dokumen yang terkait dengan penelitian dianalisis. Dokumen-dokumen tersebut mencakup nilai yang diperoleh mahasiswa pada matakuliah tertentu, Perangkat perkulaihan 
seperti GBPP dan SAP serta alat evaluasi yang digunakan oleh Dosen seperti UTS dan UAS.

Penelitian yang dilakukan termasuk merupakan penelitian deskriptif-kualitatif. Penelitian ini berusaha mendeskripsikan dan menginterpretasi apa adanya dari tugas yang dirancang oleh peneliti (Best 1982). Data yang berupa produk perencanaan dan hasil proyek mahasiswa calon guru matematika yang terstruktur terkumpul rapih dalam portofolio tugas mahasiswa (penilaian validator) maupun pernyataan dalam angket yang nantinya dianalisis secara deskriptif.

Dalam penelitian ini, langkah-langkah yang dilakukan dapat dibagi menjadi tiga tahap, yaitu tahap pra-penelitian, tahap pelaksanaan, dan tahap pasca penelitian. Rincian kegiatan yang dilakukan pada setiap tahap adalah sebagai berikut :

1. Tahap pra-penelitian

a. Penentuan kelas-kelas yang akan dijadikan subjek studi lapangan.

b. Persiapan instrumen studi lapangan, misalnya penyusunan format lembar observasi, format wawancara dan angket.

2. Tahap Pelaksanaan

Pengambilan data berdasarkan identifikasi masalah, diantaranya adalah:

a. Observasi proses pembelajaran, Fasilitas dan sarana prasarana Pembelajaran

b. Wawancara dosen untuk mengetahui persiapan mengajar, hasil evaluasi terhadap pembelajaran dan motivasi dosen untuk meningkatkan mutu pembelajaran.

c. Wawancara dengan petugas perpustakaan dan dosen wali untuk mendapatkan informasi mengenai hal mendukung diketahuinya kreatifitas mahasiswa calon guru matematika di perkuliahan multimedia pembelajaran matematika

d. Pemberian angket pada mahasiswa untuk mengetahui kreatifitas mahasiswa calon guru matematika di perkuliahan multimedia pembelajaran matematika.

e. Pemberian angket pada dosen untuk mengetahui karakteristik dosen Multimedia pembelajaran matematika dalam memberikan perkuliahan untuk mahasiswa calon guru matematika

3. Tahap akhir

a. Pengembangan teori berdasarkan data yang diperoleh.

b. Penyusunan laporan. 
Secara umum, kegiatan penelitian ini dapat dilihat pada alur penelitian gambar 1 berikut:

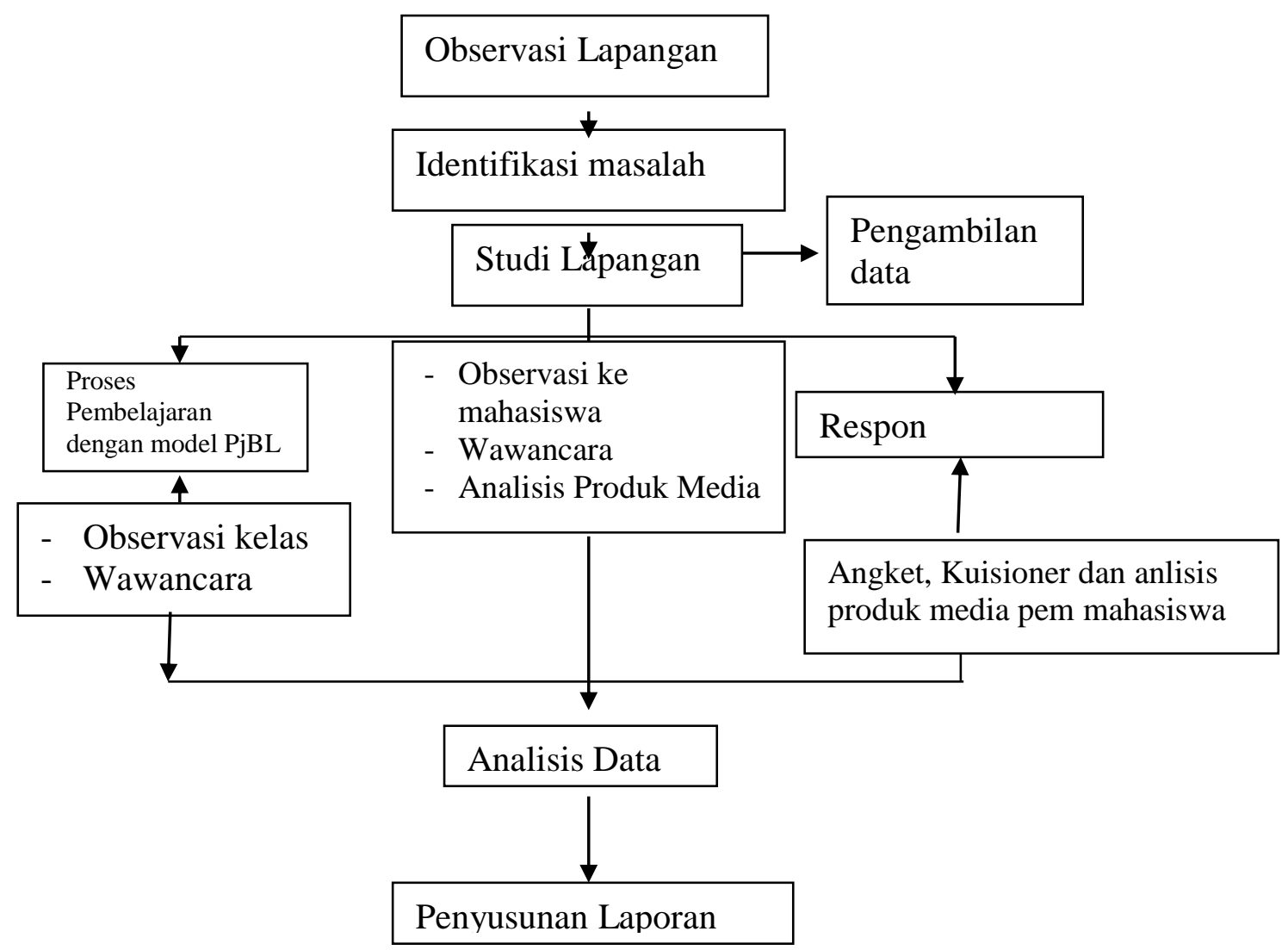

Gambar 1. Alur Penelitian

4. Hal - Hal yang dilaporkan

Berdasarkan rumusan masalah dan data yang telah diperoleh, maka hal-hal yang akan dilaporkan dalam penelitian ini adalah sebagai berikut:

a. Deskripsi mengenai kreatifitas mahasiswa calon guru matematika FKIP Unswagati Cirebon dalam upaya mengaitkan media pembelajaran dengan kearifan lokal budaya cirebon saat mengikuti perkuiahan multimedia pembelajaran matematika.

b. Produk media pembelajaran berbasis budaya lokal cirebon yang dibuat oleh mahasiswa calon guru matematika tingkat III.

c. Harapan dan penilaian mahasiswa calon guru matematika terhadap mata kuliah media pembelajaran matematika dan kinerja dosen pengampunya.

\section{HASIL DAN PEMBAHASAN}

Data hasil penelitian terdiri atas (1) Produk media pembelajaran matematika berbasis budaya lokal seperti flipchrat, alat peraga, alat permainan edukatif dan juga sarana untuk 
medokumentasikannya, (2) Presentasi respon mahasiswa terhadap penyelenggaraan program perkuliahan media pembelajaran berbasis proyek, dan (3) Hasil telaah ringkasan wawancara dengan mahasiswa. Data tersebut kemudian dianalisis, direkap dan disajikan, selanjutnya diuraikan untuk menjawab pertanyaan penelitian.

\section{Produk Media Pembelajaran matematika berbasis budaya Lokal Cirebon}

Berikut disajikan beberapa contoh media pembelajaran matematika berbasis budaya lokal cirebon yang telah diproduksi oleh mahasiswa selama mengikuti program perkuliahan media pembelajaran berbasis proyek. Adapaun tindak lanjut dari produk ini adalah akan di buat pameran kreatifitas mahasiswa agar bisa diakses, dipelajari dan disebarkan secara luas baik untuk mahasiswa maupun untuk pengetahuan umum (Kurniawan 2014).

1. FlipChart (Carta) Pembelajaran Matematika

Flipchart adalah lembaran - lembaran kertas yang membentuk album atau kalender yang berukuran cukup besar sebagai flipbook yang disusun dalam uruta yang diikat atau direkatkan pada salah satu bagian (Biasanya bagian atasnya). Dalam penggunaannya dapat dibalik jika pesan pada lembaran depan yang sudah ditampilkan dan digantikan dengan lembaran berikutnya. Flipchart merupakan salah satu media cetakan yang sangat sederhana dan cukup efektif. Penyajian Informasi flipchart dapat berupa Gambar, Huruf, Diagram dan juga angka. Berikut disajikan beberapa flipchart berbasis budaya lokal cirebon yang dijadikan sebagai media pembelajaran matematika. Gambar 4 ini merupakan flipchart kreasi mahasiswa caon guru matematika tingkat III prodi pendidikan matetamika FKIP Unswagati Cirebon.

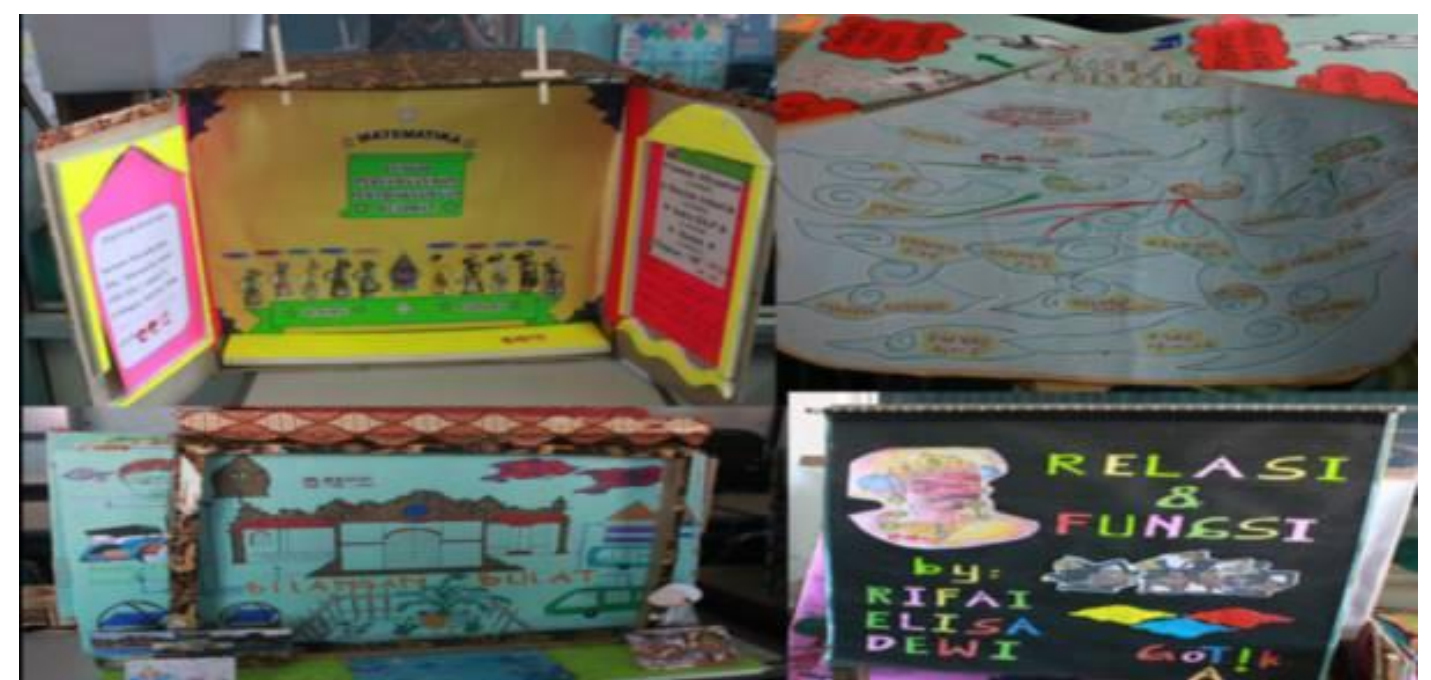

Gambar 2. Beberapa Flipchart berbasis budaya lokal cirebon hasil karya mahasiswa calon guru matematika tingkat III Program studi pendidikan matematika FKIP Unswagati Cirebon 


\section{Alat Peraga dan Alat Permainan Edukatif pembelajaran matematika}

Alat peraga adalah alat untuk menerangkan atau mewujudkan konsep matematika. Adapun yang dimaksud alat adalah alat untuk menghitung, menggambar, mengukur, dsb., seperti kalkulator, komputer, mistar, jangka, busur derajat, klinometer, dsb. Sedangkan yang dimaksud alat pembelajaran yaitu alat bantu yang digunakan untuk memperlancar pembelajaran matematika, seperti OHP, komputer, papan tulis, spidol/ kapur, dsb. Suatu benda dikatakan tidak mempunyai arti apa-apa akan terjadi jika benda tersebut tidak dikaitkan dengan topik dalam pembelajaran matematika. Alat peraga yang baik harus memenuhi beberapa kriteria, diantaranya: (1) Dapat menjelaskan konsep secara tepat, (2) Menarik, (3) Tahan lama, (4) Multi fungsi (dapat dipakai untuk menjelaskan berbagai konsep), (5) Ukurannya sesuai dengan ukuran siswa, (6) Murah dan mudah dibuat, dan (7) Mudah digunakan. Sedangkan Alat Permainan Edukatif adalah APE adalah segala sesuatu yang dapat digunakan sebagai sarana atau peralatan untuk bermain yang mengandung nilai edukatif (pendidikan) dan dapat mengembangkan seluruh kemampuan anak. Berikut disajikan Ganbar alat peraga dan alat permainan edukatif untuk pembelajaran matematika pada gambar 3 .

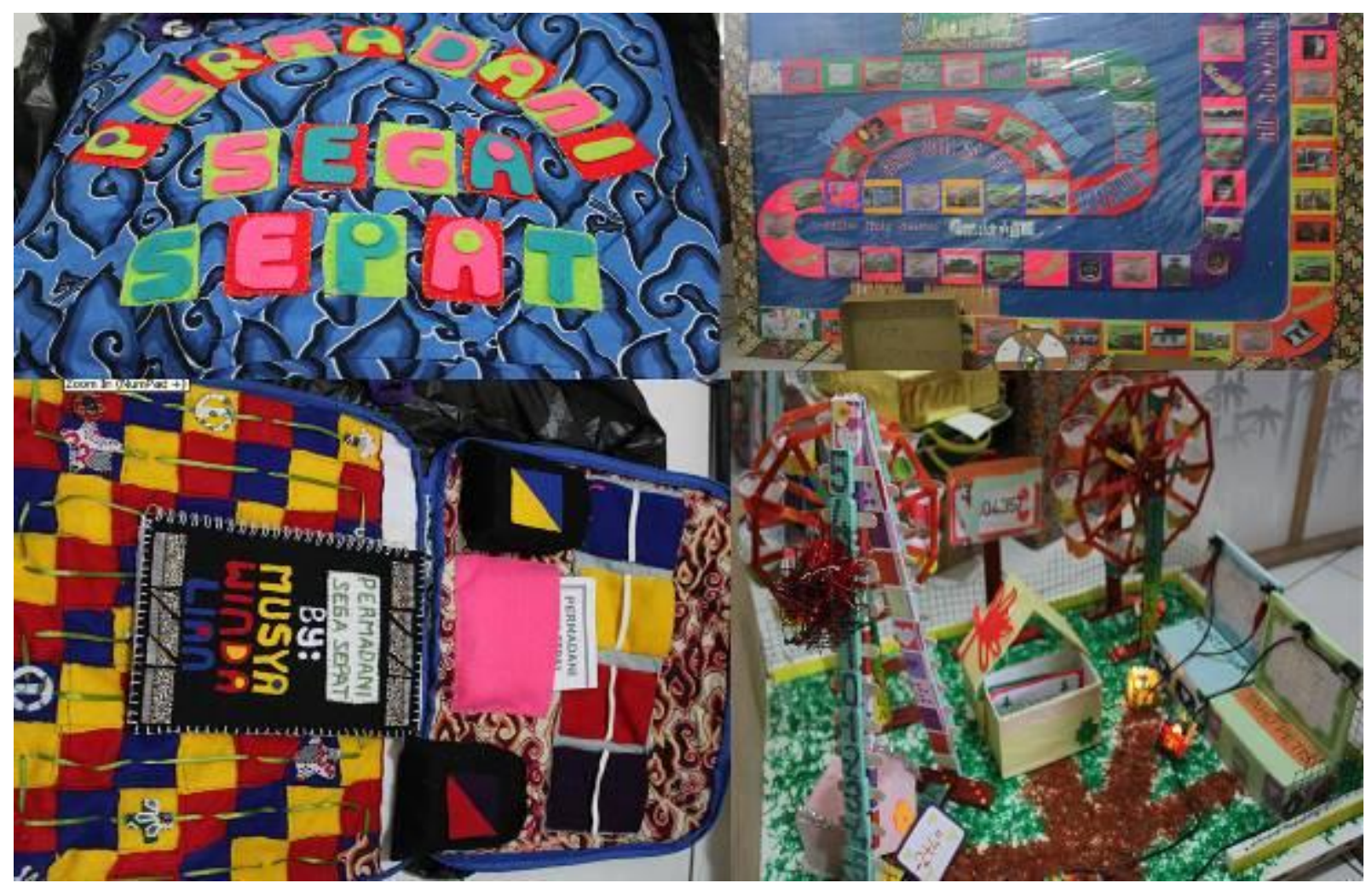

Gambar 3. Beberapa Alat Permainan Edukatif berbasis budaya lokal cirebon untuk pemebelajaran matematika 


\section{Modul Alat Peragat Atau Alat Permainan Edukatif Matematika}

Modul adalah salah satu bahan ajarb yang dikemas secara sistematis dan menarik. Modul ini memuat petunjuk tatacara penggunaan alat peraga atau alat permainan edukatif yang dibuat. Isi Modulnya diantaranya: pendahuluan Latar belakang, konsep dan ide mengapa mendesign alat peraga atau permainan edukatif ini. Manfaat atau kegunaan alat peraga atau permainan edukatif yang bisa diperoleh. Pembahasan yang terdiri atas nama alat peraga atau permainan edukatif, alat dan bahan pembuatan, proses pembuatan alat peraga atau permainan edukatif dan terakihir petunjuk penggunaan atau pengoprasian menjalankan alat peraga atau permainan edukatifnya. Lembar kerja atau lembar bimbingan siswa dalam menggunakan alat peraga atau permainan edukatif yang dibuat. Profil dan deskripsi kerja kelompok yang membangun dan membuat tugas ini. Dokumentasi berupa gambar alat peraga atau permainan edukatifnya, foto cara penggunaan, dan foto proses pembuatanya,

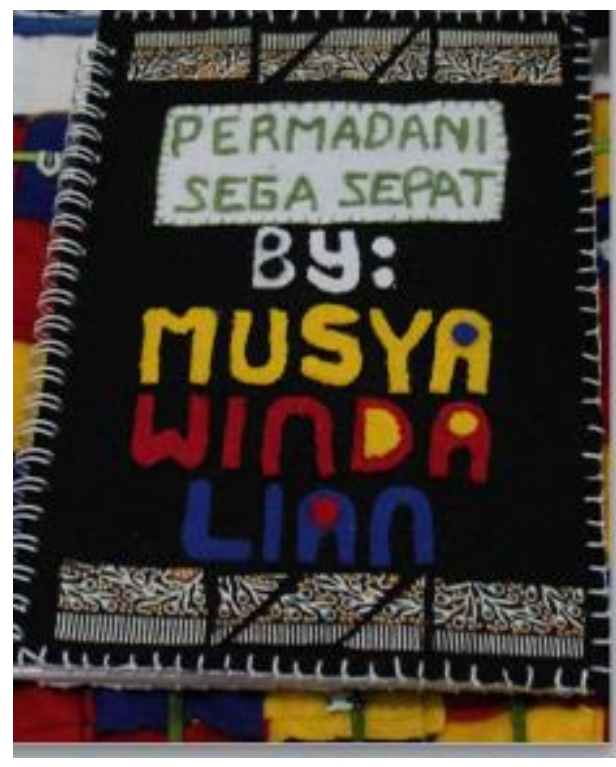

Gambar 4. Beberapa Modul yang menjelaskan penggunaan alat peraga atau alat permainan edukatif pembelajaran matematika

\section{Artikel Alat Peraga atau Alat Permainan Edukatif Matematika}

Artikel ini merupakan ringkasan dari modul yang telah dibuat. Artikel ini dimaksudkan untuk membuat sebuah poster atau banner yang berisikan gambaran umum mengenai alat peraga atau alat permainan edukatif berbasis budaya lokal cirebon yang telah dibuat. Berikut disajikan beberapa artikel pada gambar 5 sebagai contoh. 


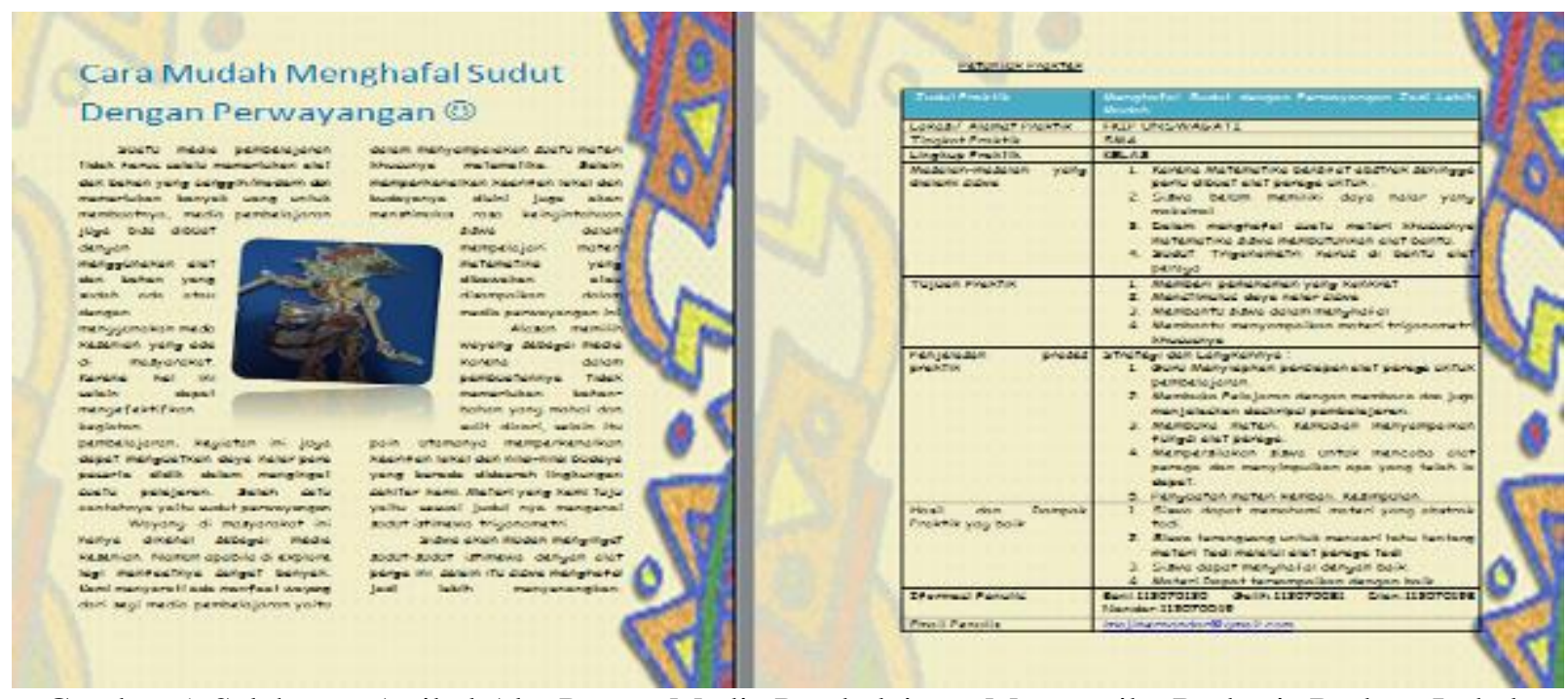

Gambar 5. Salah satu Artikel Alat Peraga Media Pembelajaran Matematika Berbasis Budaya Lokal Cirebon

\section{Video Tutorial Alat Peraga atau Alat Permainan Edukatif Matematika}

Video tutorial ini dibuat dengan maksud untuk memandu bagaimana menggunakan alat peraga dan alat permainan edukatif berbasis budaya lokal cirebn yang telah dibuat. Video -Video ini dapat diakses secara Online melalu situs www.youtube.com. Berikut disajikan beberapa tampilan video tutorial dalam gambar 6

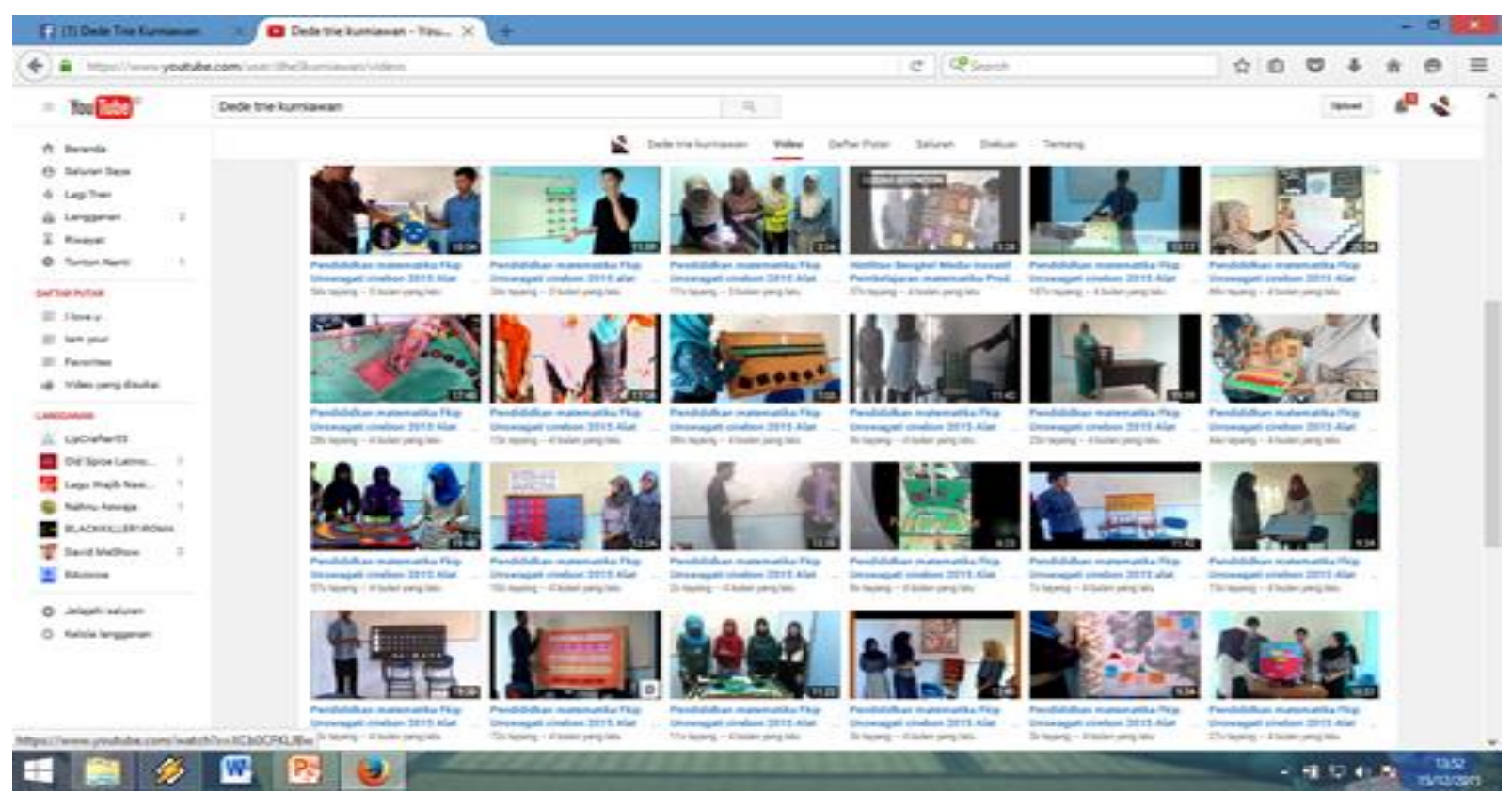

Gambar 6. Kumpulan Beberapa video mengenai presentasi mahasiswa calon guru matematika tingkat III prodi Pendidikan matematika Unswagati dalam membuat dan memeragakan media pembalajaran berbasis budaya lokal cirebon. (https://www.youtube.com/user/dhe3kurniawan) 
6. Bengkel MIPA (Media Inovatif Pembelajaran Matematika) di Unswagati

Bengkel MIPA (Media Inovatif Pembelajaran Matematika) ini merupakan sebuah ruangan tempat menyimpan dan memamerkan media pembelajaran berbasis budaya lokal cirebon yang dibuat oleh mahasiswa tingkat III Prodi pendidikanmatematika FKIP Unswagati Cirebon. Bengkel MIPA ini pernah dikunjungi oleh salah satu profesor matematika yang berasal dari Universitas Negeri Surabaya pada tahun 2015. Melalui Bengkel MIPA Ini di harapkan bisa menjadi tempat wisata edukatif bagi anak anak dalam mempelajari matemattika sekaligus dapat menajdi ruang bermain sambil belajar.

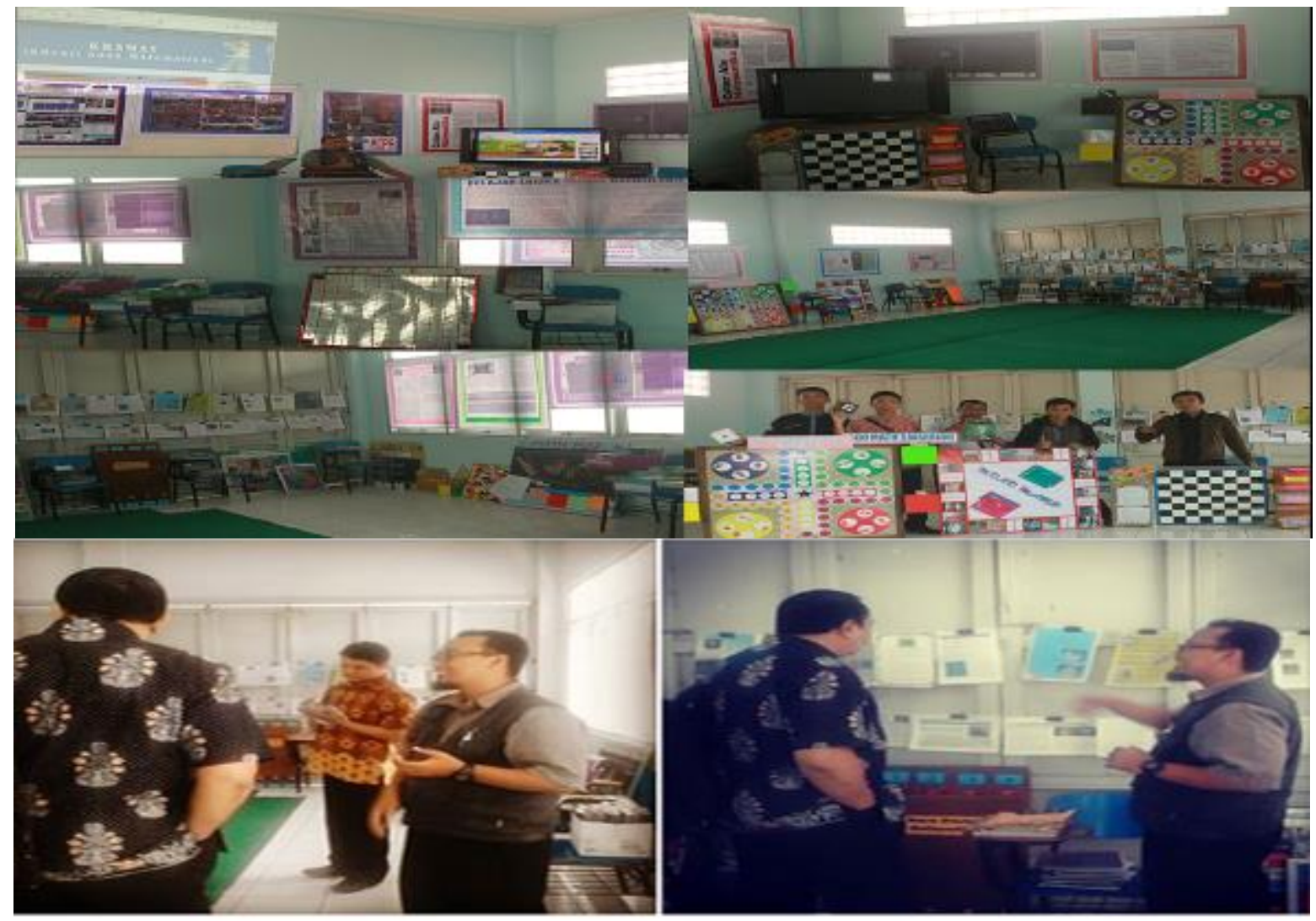

Gambar 7. Aktivitas Bengkel MIPA (Media Inovatif Pembelajaran Matematika) di Kampus 2 Unswagati Cirebon

Data respon mahasiswa terhadap program proyek media pembelajaran matematika berbasis budaya lokal cirebon diperoleh dari kuisioner yang dibagikan ke semua mahasiswa pendidkan matematika tingkat III peserta mata kuliah media pembelajaran dengan dosen Dede Trie Kurniawan, S.Si., M.Pd. Hasilnya dapat dilihat pada Rekapitulasi data respon mahasiswa terhadap program proyek media pembelajaran berbasis budaya lokal cirebon yang disajikan pada Gambar 8 . 


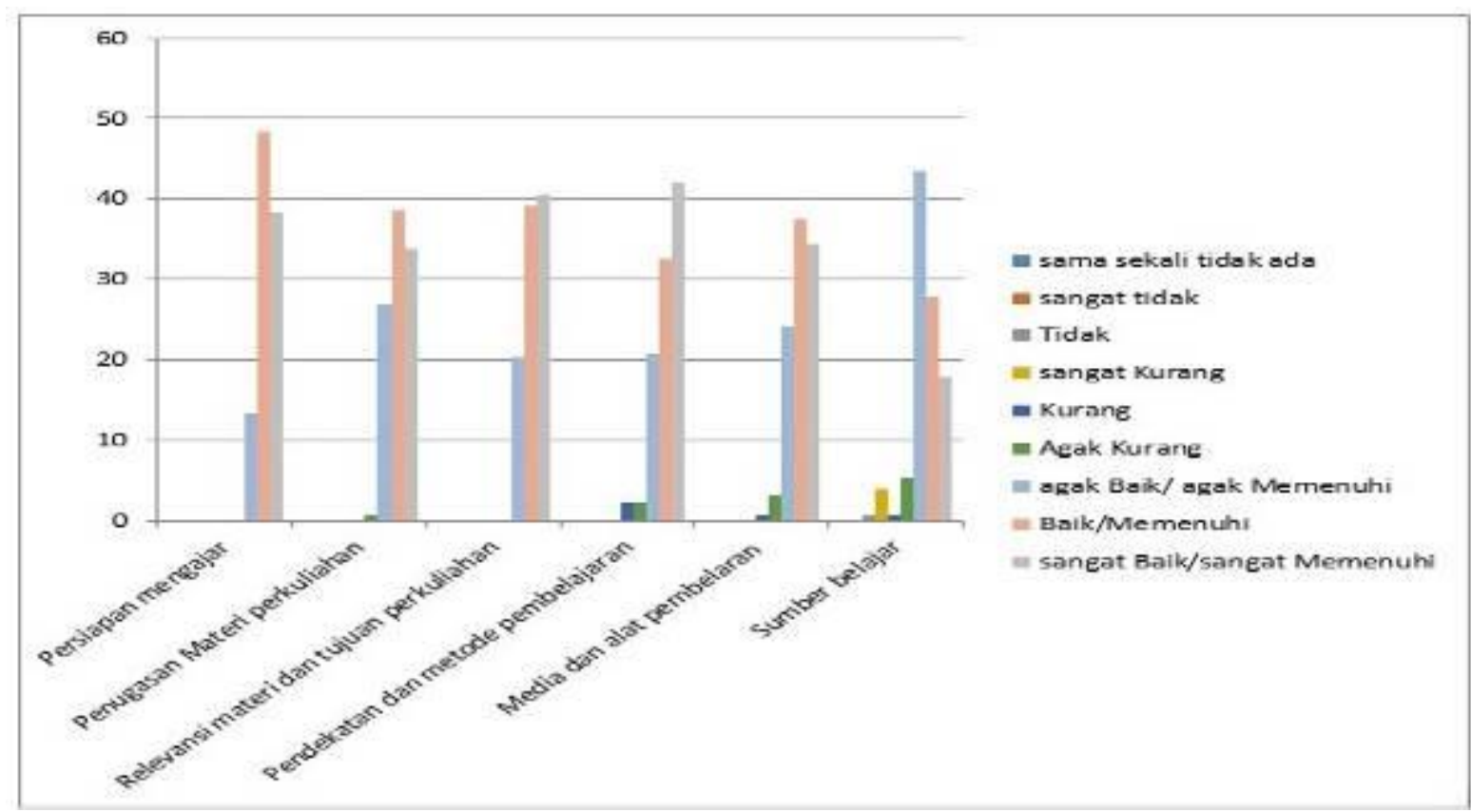

Gambar 8. Respon mahasiswa terhadap model PjBL yang diterapkan dalam perkuliahan media pembelajaran

Salah satu keterampilan yang harus dimiliki oleh calon guru matematika adalah mampu dan dapat mempersiapkan serta menggunakan media pembelajaran dalam proses kegiatan belajar mengajar dikelas. Media adalah segala sesuatu yang dapat digunakan untuk menyalurkan pesan dari pengirim kepada penerima. Media yang berfungsi untuk menyampaikan pesan pembelajaran sehingga dapat merangsang pikiran, perasaan, perhatian, dan minat siswa yang menjurus kearah terjadinya proses belajar disebut dengan media pembelajaran. Media pembelajaran adalah alat, metode dan teknik yang digunakan dalam rangka lebih mengefektifkan komunikasi dan interaksi antara guru dan siswa dalam proses pembelajaran di sekolah.

Matakuliah yang mempersiapkan calon guru matematika agar dapat memiliki kompetensi yang baik dalam penggunaan media pembelajaran adalah matakuliah Multimedia pembelajaran matematika untuk mahasiswa tingkat III yang berbobot 2 SKS. Mata Kuliah ini dimaksudkan untuk memberikan dasar pengetahuan dan membuat kreasi media pembantu penyampaian pembelajaran matematika. Topik - topiknya meliputi : peran dan fungsi media dalam proses pembelajaran, Mind map sebagai media sederhana, Peran TIK dalam media pembelajaran, wapik sebagai wahana web inovatif, ethnomatematic dan etnosains dan kumpulan artikel media alat peraga dan alat permainan edukatif dalam pembelajaran 
matematika. Adapaun yang menjadi capaian dari matakuliah ini yaitu Mampu menghasilkan produk media pembelajaran berbasis budaya lokal dalam menunjang kegiatan pembelajaran Matematika serta dapat mempraktekan dengan cara penggunaan dan pemanfaatanya dikelas.

Secara garis besar respon mahasiswa atas kinerja dosen dalam menajalankan model pembelajaran berbasis proyek dalam membuat media pembelajaran matematika yang berakar budaya lokal cirebon adalah baik. Menurut mahasiswa, dosen sudah bisa menyampaikan materi perkuliahan dengan sistematika yang baik, merespon permasalahan dengan baik, memberikan materi perkuliahan sesuai dengan harapan mahasiswa, dapat memotovasi dan mengaktifkan mahasiswa. Dosen dipandang memiliki kesesuaian dengan bidang keahlian yang disampiakan.

Adapun beberapa catatan untuk perbaikan dan saran dalam pelaksanaan kegiatan perkuliahan ini diantaranya adalah perlu menambah waktu yang lebih lama, perlu ruangan yang lebih luas dan leluasa dalam pelaksanaannya, perlu mengadakan kegiatan semacam seminar untuk menampilkan kreatfitas mahasiswa dalam pembuatan media pembelajaran berbasis budaya lokal cirebon. Beberapa harapan dari mahasiswa diantaranya adalah menunggu terbitnya sebuah buku yang berisi kumpulan karya media pembelajaran hasil karya mahasiswa program studi pendidikan matematika FKIP Unswagati cirebon yang bisa lebih disebarluaskan .

\section{KESIMPULAN}

Berdasarkan data dan analisis hasil penelitian yang telah dilakukan tentang efektifitas pelaksanaan model pembelajaran berbasis proyek sebagai sarana peningkatan kreatifitas mahasiswa calon guru matematika dalam membuat media pembelajaran berbasis budaya lokal cirebon dapat disimpulkan bahwa kegiatan ini efektif dan berhasil dalam pelaksanaannya, dikarenakan mahasiswa memberikan respon yang positif dan baik terhadap kegiatan perkuliahan yang termasuk produk media yang dihasilkannya. Kampus perlu meningkatkan Sarana dan prasarana dalam menunjang kegiatan pembelajaran salah satunya perlunya sebuah bengkel kreatfitas dalam membuat media pembelajaran. Kinerja dosen dapat dikategorikan baik. Hal ini karena Dosen sudah bisa menyampaikan materi pelatihan dengan sistematika

yang baik, merespon permasalahan dengan baik, memberikan materi pelatihan sesuai dengan harapan peserta, dapat memotovasi dan mengaktifkan peserta dan dosen memiliki kesesuaian dengan bidang keahlian yang disampaikan. Adapun harapan dari mahasiswa adalah menunggu 
terbitnya sebuah buku yang berisi kumpulan karya media pembelajaran hasil karya mahasiswa program studi pendidikan matematika FKIP Unswagati cirebon yang bisa lebih disebarluaskan dapat terealisasi.

\section{REFERENSI}

Ajeyalemi, D. A. (1993). Teacher Strategies Used by Exemplary STS Teachers. What Research Says to The Science Teaching. Washington DC: National Science Teachers Association

Alwasiyah, A.C., Suryadi, K, dan Karyono, T. (2009). Etnopedagogi: Landasan pendidikan dan pendidikan guru. Kiblat Buku utama. Bandung

Best, J.W. (1982). Metodologi Penelitian Pendidikan (Terjemahan oleh Sanapiah Faisal). Surabaya: Usaha Nasional

Kurniawan, D.T. (2013). Kreativitas Mahasiswa Calon Guru Matematika melalui Model Pembelajaran Berbasis Proyek (Project Based Learning (PjBL) Pada Mata Kuliah Program Komputer. Makalah Seminar STKIP Siliwangi Bandung

Kurniawan, D.T. (2014). Kajian Nilai Kearifan Lokal pada Tradisi Nadran Masyarakat Cirebon Sebagai Sumber Pembelajaran Ilmu Pengetahuan Alam (Studi Deskriptif Analitis Tradisi Pesta Laut Masyarakat Cirebon). Makalah SPs UPI Bandung

Kurniawan, D.T. (2014). Modul MIPA (Media Inovatif Pembelajaran Matematika). Pendidikan matematika FKIP Unswagati Cirebon.

Purnawan, Y. (2007). Desain Penulisan: Deskripsi Model PBL/ Pembelajaran Berbasis Proyek. Dari http://yudipurnawan.wordpress.com/2007/12/18/deskripsi-model-pbl pembelajaran-berbasis-proyek/

Rustaman, N.Y. (2014). Ethnopedagogy, Ethnosains \& Indigneous Sains. Slide Perkuliahan Etnosains. Pendidikan IPA SPs UPI Bandung.

Suratno, T. (2010). Memaknai Etnopedagogi sebagai landasan pendidikan guru di universitas pendidikan indonesia. Proceedings the 4th International conference on teacher education: Join Conference UPI \& UPSI. Bandung

Turmudi. Ethnomatematik. Slide pemaparan seminar di Unswagati Cirebon 